


\section{Definiendo el papel del auxiliar de conversación en el aula bilingüe}

\section{Extracto:}

El auxiliar de conversación ha disfrutado de un papel clave dentro de los programas bilingües de la Comunidad de Madrid (CM) durante años. Sin embargo, este papel ha sido malinterpretado tanto por los profesores como por los mismos auxiliares, lo que conduce a que no se les saque el máximo partido. A veces realizan tareas que no son propias o no cumplen con los requisitos, y a menudo los resultados incluyen un efecto no deseado. Este estudio se ha basado en una encuesta a profesores y auxiliares involucrados en los tres mayores programas bilingües de la CM (el programa bilingüe público de la $\mathrm{CM}$, el programa Bilingual English Development and Assessment [BEDA] y el programa bilingüe-bicultural de la Unión de Cooperativas de Enseñanza de Trabajo Asociado de Madrid [UCETAM]) en la que se les preguntaba sobre sus expectativas y experiencias respecto al papel del auxiliar en el aula de educación primaria. Se analizó la documentación oficial de los tres programas, y los resultados se compararon con los del análisis de los cuestionarios. Se ha concluido que los profesores y auxiliares tienen expectativas en común al comienzo del año académico, pero estas no siempre corresponden a las tareas que realizan en la práctica. El estudio también ha revelado que las prácticas del aula no siempre corresponden a las descripciones del rol del auxiliar en la documentación oficial. En función de estos hallazgos, se recomienda una mejora en la conciliación de las prácticas del aula con las descripciones oficiales del papel del auxiliar. Esto incluye una reflexión sobre el papel del auxiliar, la formación de profesores y auxiliares y una mejor comunicación desde las Administraciones con el fin de definir y optimizar su papel como recurso de aula.

Palabras clave: auxiliar de conversación, colegios bilingües, rol del profesor, Comunidad de Madrid (CM), expectativas.

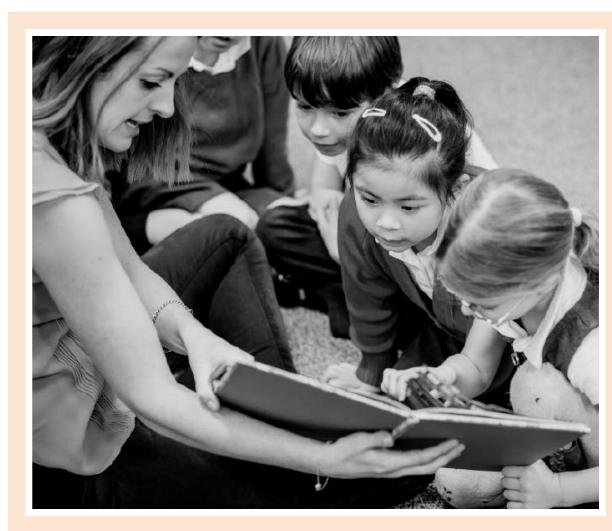

\section{CONTEXT}

There are three main bilingual programs currently operating within the CM (Spain). They are the publicly funded bilingual program (hereinafter, the $\mathrm{CM}$ bilingual program), the BEDA program run by Federación Española de Religiosos de Enseñanza-Titulares de Centros Católicos (FERE-CECA), and the UCETAM Bicultural-Bilingual and Bicultural programs. The BEDA and UCETAM programs currently function in private and semi-private (concertado) schools. The three programs share many characteristics; most importantly, they all involve a greater number of classroom hours in English than is suggested by the local curriculum. Most achieve this through a combination of language classes and content classes taught in English (content and language integrated learning [CLIL]), with the exception of the UCETAM Bicultural program which does not include the CLIL approach.

One key player within these programs is the foreign LA. They are young people, native of English-speaking countries, who spend at least one academic year in a school to support the learning of the English language (Ministerio de Educación, Cultura y Deporte, 2014). LAs are meant to support teachers by providing a native model of the English language, fomenting intercultural awareness, and supplying an authentic need for communication in English within the classroom. These aims are often addressed through the use of information and communication technologies (ICT) in the classroom, though a native speaker can also provide essential support and authenticity for learning a foreign language. 


\subsection{LAs in the CM bilingual program}

At the start of the 2014-2015 academic year, there were over 1.900 LAs working in primary and secondary public schools in the CM. Some were hired by the Ministry of Education, Culture and Sports while others were employed directly by the $\mathrm{CM}$. They came from Austria, Australia, Belgium, Canada, France, Germany, Ireland, Italy, New Zealand, the United Kingdom, and the United States. Of this total number, there were over 1.000 English speakers appointed to public primary schools and over 400 to public secondary schools as part of the Bilingual Program, 282 LAs to support the English department at non-bilingual schools, and others dedicated to supporting other languages (CM, 2014, p. 2). According to the Language Assistant Handbook for 2014-2015, the main objective of the assistants' work and presence in the classrooms was to help children learn languages in a more direct and personal way and learn about the assistants' cultures, traditions, and lifestyles. This handbook serves as an official description of the rights and responsibilities that apply to all the language assistants mentioned above.

Assistants have a number of duties and obligations during their time at the school, and they are asked to report any irregularities to the $\mathrm{CM}$, especially being asked to take on responsibilities beyond the scope of their position. Among their duties, LAs are to always speak their mother tongue and be in constant contact with students, ideally motivating students and fomenting interest in their language and culture. They are asked to help teachers plan lessons and provide linguistic support in the classroom so as to reinforce students' oral skills and promote knowledge of other cultures (CM, 2014).

LAs are expected to follow the teachers' instructions and cooperate with them to ensure that lessons run smoothly. Additionally, they are encouraged to propose creative activities and resources for the classroom and provide teaching-learning materials. They accompany students to the language laboratory, computer room and multimedia center, and may take part in a variety of school-wide activities as decided by the school administration. However, because LAs are not necessarily qualified teachers, they should not be responsible for assessing supervising students. They are not to be involved with any teachers' responsibilities, such as meeting parents, supervising the playground or dining hall, programming lessons or writing year-end reports (CM, 2014).

The role of LAs has generally been seen as valuable by all involved in the CM bilingual program. Teachers have mainly valued their input in the foreign language and their contributions to teaching resources, though many have considered that LAs should be trained teachers rather than university students (Fernández and Halbach 2010, p. 248). In a study run by the Federación de Trabajadores de la Enseñanza-Unión General de Trabajadores (FETE-UGT) (2014), a Spanish workers' union, $61 \%$ of teachers (including those involved in bilingual programs and others that were not) valued the role of LAs as positive in their schools. Students have also generally found LAs to be quite helpful, kind and sensitive and have credited LAs for helping them master English. In response to a survey, secondary students who had studied in a primary bilingual school overwhelmingly found LAs to be «irreplaceable and [...] absolutely responsible for their linguistic and cultural advancements» (Gerena and Ramírez-Verdugo 2014, p. 127).

\subsection{LAs in the BEDA program}

The BEDA program also employs a large number of language assistants from English-speaking countries. In 2014-2015 there were 383 LAs working in the CM, including 191 who worked in pre-primary, 279 in primary, 203 in secondary, 97 in upper-secondary, and 25 in vocational training, many of whom shared their hours between more than one educational stage 2 . Their main aim is to add an intercultural dimension to the school and the classroom, as they are «ambassadors for their countries, their customs and their educational systems» (FERE-CECA, 2014, p. 1). Overall, they offer their assistance to the teachers, engage students in conversation, and aim to make the classes more interesting and dynamic.

BEDA LAs are meant to speak English throughout the school, prepare classes and plan their interventions with the teachers, and propose teaching materials and creative activities for the classroom. They work with groups

\footnotetext{
2 Esther Momprade (BEDA organization), e-mail message to author, February 24, 2015.
} 
of students and under the indications of the school director and their assigned teachers. They have a duty to help students with phonetic and grammatical corrections and bring them closer to their home cultures. In contrast to other programs, they are also often asked to assess students' speaking abilities as a complement to the main teacher's assessment (FERE-CECA, 2014).

\subsection{LAs in the UCETAM program}

A conversation with the director of the programs revealed that the number of LAs working in the UCETAM program is significantly smaller than that of the other programs in Madrid, due to the relative smaller number of schools involved. The UCETAM organization employed 130 LAs in 2014-2015, and they worked to support the linguistic and cultural competences of the students. $96 \%$ of the UCETAM LAs of the same year were from the United States, giving the Bicultural-Bilingual and Bicultural programs a significant American cultural influence ${ }^{3}$.

Though LAs and bilingual schools receive a handbook from the UCETAM organization, the exact responsibilities and duties are left to the discretion of each school. Even so, the description of responsibilities that follows has been summarized from the 2012-2013 Schools Handbook as a point of reference ${ }^{4}$.

The Handbook states that LAs are not teachers, but rather assistants who collaborate with full teachers. Therefore, they are not responsible for student discipline or evaluation, and should never substitute a teacher. They are meant to initially observe the curriculum that is in place in the school then collaborate with teachers in activities planning. It is hoped that LAs will take initiative when applying their own cultural knowledge to the classes they assist with, and encourage student interest in foreign cultures. LAs should focus on helping students improve their oral English skills by encouraging student participation and teamwork. LAs are also asked to be creative and provide resources in order to develop lessons on the North American and Englishspeaking cultures (UCETAM, 2012).

\footnotetext{
${ }^{3}$ José Manuel Caballero de Zulueta (UCETAM organization), interview with author, September 24, 2014.

${ }^{4}$ The 2012-2013 handbook was the only one publicly available at the time of the study.
}

\subsection{Misinterpretations of the role of the LA}

Despite the fact that the role of the LA seems rather straight-forward in the handbooks described, previous studies suggest that it is often misinterpreted by both LAs and teachers. Hibler (2010) found that $40 \%$ of the LAs surveyed were unsure of their role, $60 \%$ were only somewhat sure of their role, and no one was completely sure. At the same time, $100 \%$ of the teachers surveyed responded that they had discussed their expectations with the LA. The same author recognizes that LAs seemed to depend highly on the teacher to designate the roles in the classroom and until this is done, they are unsure of what to do. Once functions and tasks were defined for each person, LAs reported more positive collaborations in the classroom.

LAs are often given a less important role to play in the classroom, which is perceived by students. As students are used to working with grammar and a textbook, they see LA-led activities related to culture or oral skills as less important and even frivolous (Ortega Cebreros, 2003; Scobling, 2011). Gerena and Ramírez-Verdugo (2014) suggest that LAs should be more integrated as a linguistic and cultural resource, as they had also witnessed LAs performing menial chores such as making photocopies and preparing materials. The danger here is that students see the LA as a less powerful player in the classroom and may lose respect for him or her, making it much more difficult for the LA to control the classroom when leading an activity.

Overall, the LA is not being used to his or her potential. This is seen in comments by LAs who stated they felt like a «one-trick pony» when asked to do singular activities from time to time (Tobin and Abello-Contesse, 2012, p. 16). Another LA felt like a bird in a cage that the teacher brought out to play with for a while before putting him back in his cage to continue with the curriculum (Scobling, 2011, p. 30). These LAs are not being integrated into the classroom as a useful tool, rather they are asked to perform once in a while to justify their presence.

As previously mentioned, there are certain tasks that LAs should not carry out since they may not be qualified teachers, including marking students' work (CM, 2014; Ministerio de Educación, Cultura y Deporte, 2014). Even so, some LAs were regularly asked to perform these tasks (Scobling, 2011). 


\section{[...] it is essential that classroom practice mirrors the situation that is described in program handbooks to enable proper training for both teachers and LAs regarding the latter's role and how to make the most of it}

LAs have often reported being left alone to teach groups of students, whether a small group or the entire class-group (Hibler, 2010; Ortega Cebreros, 2003; Scobling, 2011; Tobin and Abello-Contesse, 2012). While this is prohibited in the 2014-2015 handbook published by the Ministry, there is no mention of allowing or preventing the LA to teach or supervise a small group of students without the presence of a teacher in the 2014-2015 CM LA handbook, even though it was prohibited by the same organization's handbook for 2009-2010. This ambiguity could lead to confusion regarding the extension of the LA's duties. Likewise, an unexperienced LA who takes charge of a group of students can feel uncomfortable and unsure (Hibler, 2010), or teach inappropriate contents (Tobin and Abello-Contesse, 2012).

Given the potential of the LA as an authentic resource and the documented difficulties that stem from a misinterpretation of the role of the $L A$, it is important that teachers' and LAs' expectations match those of the program administrations. Also, it is essential that classroom practice mirrors the situation that is described in program handbooks to enable proper training for both teachers and LAs regarding the latter's role and how to make the most of it.

\section{MATERIALAND METHODS}

The current research focuses on the expectations that LAs and teachers hold at the beginning of the academic year as a result of the information provided by program administrative bodies, as well as on classroom practices as reported by LAs and teachers involved in the programs. It strives to compare and contrast program, LA and teacher expectations, then compare these with actual classroom practice. The results will describe the variation in perspective among the three groups as well as determine the areas in which the role carried out may not match the intentions set forth by each program.

Given that the objectives of the current study focus on the perceptions and expectations surrounding the role of the LA, the study was designed to collect the opinions, experiences and suggestions of those directly involved, both LAs and teachers in bilingual projects in primary schools in the CM. Contact with participants was carried out, both online and in person, from 2013 to 2015 so as to reach the maximum number of participants possible while not extending the study so long that program characteristics changed, affecting the results. The data was collected through the use of online and printed questionnaires and made use of both quantitative and qualitative data.

\subsection{Data collection}

Program documentation was consulted in order to obtain official descriptions of the role of the LAs and the main characteristics of each program. Said documentation included the informational websites of each of the programs (CM, BEDA and UCETAM) and the LA handbooks that were available for $2014-2015^{5}$. The information obtained from the program documentation is summarized above in the Literature Review, and a brief analysis of this information is provided below in the Results and Discussion.

Four questionnaires were then administered: two to LAs and two to teachers, the first set at the beginning of the academic year and another at the midpoint. The initial questionnaires were distributed in October and were designed to collect first impressions and expectations regarding the LA's role in the classroom based on the information received in training and orientation and

\footnotetext{
5 The handbooks that were consulted included the BEDA Guidelines of Best Practices for Conversation Assistants for 2014, the Language Assistant Handbook, CM for School Year 2014-2015, and the Cooperative Bilingual Schools Bilingual Program UCETAM Schools Handbook 20122013. This last one was consulted due to lack of access to a more recent version.
} 
on previous experience. The follow-up questionnaires were distributed in January and February and meant to gather participants' experiences in the classroom.

The questionnaires contained a series of closed questions including a combination of list, category, and scale items (Nunan, 1992), as well as open questions, to provide a rich set of data. Participants were first asked for demographic information to ensure their inclusion in the target population. Then, they were asked to describe their expectations, opinions, and experiences related to the role of the LA through both open and closed question types. Each item was written with the target participant in mind, whether LA or teacher, and designed to allow cross analysis among the four questionnaires.

The questionnaires were first piloted to LAs from previous years and teachers in order to detect any errors. Afterwards, they were distributed in both online and printed formats to the target population in order to reach a maximum number of participants.

\subsection{Data analysis}

The data obtained from the questionnaires was compiled into a spreadsheet by downloading the online responses and manually entering the written responses. The data was then analyzed to remove any repeated responses by eliminating those with the same contact information or with the same or almost exact open answers. Next, each response was coded uniquely to allow for later retrieval and correlations.

The quantitative data were analyzed according to the type of question item. The list items allowed more than one response to be marked, and each of these marks was counted as a response. The total number of these responses was divided by the number of participants to obtain a percentage of participants that chose each response.

The category items allowed participants to choose only one response from the categories presented in each item. These responses were totaled and divided by the number of respondents to each question to obtain a percentage of participants that marked each category. Finally, the scale items included affirmations that could be rated from 1 to 5 ( 5 being the most positive in each case). The results were presented in two ways: as a category item with percentages for each option, and as an average rating with a reported standard deviation.
The responses to the open questions, or the qualitative data, were analyzed through key word analysis. Key words were assigned to each response as each theme was identified, and they were then categorized into more global themes to discuss with the results. Similar to the list items, the key words and global themes were totaled and divided by the number of respondents to obtain a percentage of frequency for each.

Key word analysis was also applied to the program documentation of the three main programs in the $\mathrm{CM}$, which contained descriptions of the official role of the LAs. The results were then compared with LA and teacher expectations and classroom practice in order to detect similarities and differences among the sets of data.

\section{RESULTS AND DISCUSSION}

Here, an analysis of the role of the LA as reported in the three programs' documentation is presented. This is followed by a discussion of the results of the aforementioned questionnaires.

\subsection{Program documentation}

Handbooks from the three main programs in the $\mathrm{CM}$ were analyzed in order to compare the official descriptions of the LA role. In general, the three programs refer to LAs in similar ways. The CM names the LA as such (a «language assistant») and defines them as not being part of the staff and not a qualified teacher. The CM handbook states that LAs should "cooperate» with teachers when needed, following the teachers' instructions, implying a subordinate role. UCETAM also defines the Las by saying what they are not (teachers or responsible for student discipline), and that they are present to «collaborate» with full teachers. BEDA names them «conversation assistants» and specifies that they are students, not workers, which «help» teachers in their classes. They also call them «ambassadors» to their countries, implying a strong cultural connection.

Key word analysis was applied to the lists of responsibilities and prohibitions that are present in each of the handbooks. In every case, «language» was the main consideration for the role of the language assistant, followed by «materials and resources» which included authentic materials and creative ideas for classroom activities. «Culture» 
and «activity planning» were also considerations in all of the descriptions, though both were mentioned more often in the UCETAM handbook. «Student motivation» was not included in BEDA's description of the role, but was alluded to several times in the CM handbook and once by UCETAM. Other activities included «school activities» as mentioned by BEDA as well as «meetings» and «class presentations» as mentioned by the $\mathrm{CM}$.

Only UCETAM made mention of the teaching function, stating that the LAs should eventually teach alone and uninterrupted, though always in the presence of the main teacher. It was also stated that the LA will provide reports for every trimester and may be asked to meet with parents regarding issues specific to their role within the bilingual-bicultural program. Meeting with students' parents is prohibited by the $\mathrm{CM}$ as well as supervising the playground or dining hall, duties which are delegated specifically to full teachers. All three programs prohibit the LA from substituting an absent teacher.

The BEDA handbook mentioned that LAs may be asked to support teachers in assessing the oral English level of the students, but they should not be asked to prepare or mark exams. The CM and UCETAM handbooks stated that evaluation is only the responsibility of the main teacher.

\subsection{Questionnaires}

The initial and follow-up questionnaires revealed extremely diverse experiences among LAs and teachers. Their opinions and perspectives illustrate the varied interpretations of the role of the LA, which result in professional relationships that are sometimes beneficial for both teachers and LAs, and at other times almost nonexistent or even abusive toward LAs.

81 LAs and 127 teachers participated in the initial questionnaire, while $88 \mathrm{LAs}$ and 110 teachers answer the follow-up questionnaire. The numbers are reported separately because responses were anonymous, and it is therefore not possible to know whether the same teachers and LAs participated in both the initial and follow-up questionnaires.

\subsubsection{Defining the role}

In both questionnaires, teachers and LAs were asked to define the role of the LA in their own words. In the initial questionnaire, this question was meant to reveal expectations of the upcoming academic year, to later be compared to the answers given during the year. However, since many LAs had in fact been LAs before, their answers were clearly not focused on expectations but rather experiences. For this reason, the LAs' answers from the initial questionnaire that were clearly describing experiences rather than expectations have been removed for the purpose of the current analysis. Defining nouns and verbs were reported and analyzed separately.

In the key verbs from the initial questionnaire, the main action of an LA is expected to be «assisting» the teacher. Few verbs were related to collaboration and even fewer were related to teaching the entire class. However, in the follow-up questionnaire, even though «assisting» verbs were still used by the majority, about one third of LAs and more than $20 \%$ of teachers used verbs related to teaching. This increase is consistent with the increase in use of key nouns related to teaching activities. "Collaborative» verbs were also used slightly more often than at the beginning of the year. It seems that both LAs and teachers expected LAs to have more of a secondary role than what they later carried out. Also, there is a discrepancy between LAs' and teachers' views of the former's role both at the beginning of the year and at the halfway point; teachers see LAs as more of an assistant while LAs consider themselves to be a teacher.

Regarding the activities to be carried out, the largest category of nouns used by LAs is focused on the English language, both at the beginning and in the middle of the academic year. This is consistent with the focus on language in the program handbooks. Surprisingly, only about $10 \%$ of key nouns were related to the support of culture, though this is one of the main objectives according to the program documentation. Teachers mentioned this aspect of the LA's role even less after some classroom experience, suggesting that culture is not a focus despite the intentions of the LA programs.

Few LAs and teachers consider LAs to be a resource for teaching materials, even though the LA handbooks studied mention this function as an important part of their role. In the same way, although planning was mentioned as an essential part of the role of the LA in all three handbooks, few LAs and teachers included this aspect in their descriptions.

Also noteworthy is that very few of the LAs' key nouns in the initial questionnaire were related to assisting with preparing students for external exams, while almost 
$10 \%$ of both teachers and LAs referred to this function in the follow-up questionnaires. This suggests that external exam preparation may not be considered a part of the LA's role at the beginning of the year, but generally becomes important as the class focus shifts toward this preparation in the third trimester. Even though this preparation is not mentioned in the LA handbooks, it seems to be relatively common practice in schools as seen below in the question regarding LAs' contributions to students' learning. However, if this activity is not expected by LAs or teachers, it may lead to a lack of preparation for LAs and ineffective preparation for students.

\subsubsection{Contributions to students' learning}

Both LAs and teachers were asked how LAs contribute to students' learning as well as how they help teachers. In the initial questionnaire participants were asked about their expectations and in the follow-up questionnaire about their experiences. In both cases, they were offered a series of answers to choose from and were allowed to select as many as applied. They were also able to write in an additional item if they saw fit.

Overall, the results confirm the key word analysis of the previous question. Both teachers and LAs overwhelmingly expected and experienced LA support as a pronunciation model for students. A large percentage also expected (97\%) and experienced (94\%) LAs as a language model. Most participants expected LAs to support students' learning of cultural aspects, though it did not occur in practice as often as expected. Similarly, over $80 \%$ of both LAs and teachers expected LAs to motivate students, while less than $70 \%$ experienced this positive influence during the academic year. Also, over half of $L A s$ and teachers expected LAs to provide teaching/learning resources, which occurred less often in practice. In all three cases, the decrease from expectations to experiences was also seen above in the open-ended descriptions of the role of the LA.

As seen previously, preparation for external assessment was not expected by some participants, though about three out of four noted this contribution later in the year. The LA's role in preparation for classroom assessment was expected by less than $20 \%$ of teachers and $40 \%$ of LAs. Both groups reported more experience with this aspect than had been expected. The same occurred with assistance in student discipline. As these aspects are not described in handbooks as part of the LA's role (except for oral assessment in BEDA), teachers and LAs do not generally expect to see them. Even so, LAs eventually help with assessment and discipline in many classrooms, perhaps when seen as a positive or necessary contribution.

The LA contributions as a role model and support for struggling students were not mentioned in the open answers reported above. However, when presented with these options in this list question, a significant percentage of all participants recognized these parts of the role. Three quarters of $\mathrm{LAs}$ expected to serve as a role model for students while about $70 \%$ consider that they indeed did. Interestingly, only $38 \%$ of teachers expected this to happen, and even fewer $(28 \%)$ experienced this. The same occurred with the item, extra support for struggling students, in that about half of LAs expected and reported this aspect of their work, while only $28 \%$ of teachers expected this to happen and $39 \%$ reported it occurring later in the year. Despite these differences, it is clear that LAs often contribute to the support of individual students and act as a positive influence on the student body.

\subsubsection{Assistance toward teachers}

A similar list question was presented in reference to the LA's assistance toward teachers. Some items are repeated, but all are focused on support directed toward teachers rather than students.

The results of this question corresponded well to those of previous questions. Once again, LAs as a language and pronunciation model was selected most often and their knowledge of cultural aspects second. Both groups overwhelmingly expected LAs to provide cultural knowledge and teaching/learning resources, but during the year LAs contributed less often than expected in these ways.

Most LAs expected to teach part of the class, support individual students, and teach the entire group occasionally. Fewer teachers expected LAs to do any of these things. In the end, many LAs reported teaching part of the group and supporting individuals, though less than what they had expected, and teachers reported this LA support more than what they had expected. However, over $80 \%$ of LAs taught the entire class, more than those who had expected doing so. Unexpectedly, only $38 \%$ of teachers reported this, resulting in a large discrepancy between teachers' and LAs' experiences which begs to be explained. 
Over $60 \%$ of both teachers and LAs expected LAs to help with school-wide projects and roughly a third of both groups expected them to teach English classes to teachers. However, it seems that neither project came to fruition in many cases, especially with English classes for teachers. It may be that time was too short to carry this out or that there were other logistical difficulties.

Over half of $L A s$ expected to take part in class planning and about the same percentage claim to have done so. Nonetheless, less than one third of teachers expected LAs to help in this respect, and fewer than $20 \%$ report this support. This could be due to a difference in perspective as teachers may have seen this item as formal program planning while LAs considered this day-today planning for classroom activities, as the item had been intended.

There were three tasks that few teachers expected LAs to carry out: evaluate students, administrative duties, and help with student discipline. However, in practice, teachers found that LAs undertook these tasks slightly more often than expected, though still in low percentages. On the other hand, more LAs expected to carry out these tasks, and even more report doing so. This difference between teachers' and LAs' perspectives may be because these functions are not detailed in the handbooks and some are even expressly prohibited. Administrative duties may include any number of tasks, though here in the questionnaire, roll call and correcting homework and tests were listed as examples. Therefore, checking homework and tests would have been outside the LA's normal responsibilities in every case while the other example would be permissible, though perhaps not the most effective use of the LA. All three handbooks prohibit LAs from evaluating and disciplining students with the exception of oral evaluation in the BEDA program. For this reason, the elevated numbers of $L A s$ who report having taken part in these activities is worrisome. It seems that LAs are often asked to, or see it necessary to discipline and/or evaluate students. At the same time, teachers either do not witness this or are hesitant to report that it happens, which is further cause for concern.

\subsubsection{Most effective classroom contributions}

In the follow-up questionnaire, teachers and LAs were asked by an open question for the most effective contributions LAs make to the classroom. English langua- ge contributions were the most cited by both groups ( $85 \%$ by LAs and $98 \%$ by teachers). Most teachers and $L A s$ wrote that $L A s$ were both a pronunciation and language model. Many mentioned that LAs were a reason for speaking English in the classroom and that they contributed to students' speaking skills.

About half of teachers and one third of LAs considered that LAs lend support to students, generally with their English communication skills and more specifically as a source of motivation. A few teachers and LAs mentioned that LAs gave special attention to students and made them feel more comfortable.

Another third of LAs focused on classroom support instead of individual support, suggesting that they bring different methodologies to the bilingual classroom and fun, interactive activities. A few LAs also mentioned planning activities, resources, and student discipline. Very few teachers mentioned classroom support, but those who did cited classroom activities and projects. Just one teacher mentioned that LAs provide «a different, realistic view of the experience of a teacher from another country» (my translation).

However, more teachers gave examples of teacher support, including helping the teacher improve his/her English and general teacher support, and cultural aspects, namely cultural knowledge and different points of view. LAs wrote similar tasks that corresponded to these two key words, though in smaller proportions.

Finally, even though external exam preparation is not included in any of the handbooks' role descriptions, several LAs $(12 \%)$ and teachers $(7 \%)$ mentioned it as one of the LA's most effective contributions. This warrants attention since LAs may not be prepared for one of their key tasks if they are unaware of it, or there should be more effort put into employing LAs in their intended role.

\subsubsection{Significant role in specific activities or projects}

Lastly, LAs and teachers were asked to describe any specific activities or projects in which LAs play an important role, in order to collect details of their involvement. In response, three out of four teachers mentioned general classroom activities such as celebrating festivities, games, conversation activities, role plays, reading aloud, and art or cultural activities. Over one third of LAs mentioned many of these same types of common activities. 
However, one third of LAs stated that they played an important role in external exam preparation, plus a few others mentioned oral and individual assessment. This is compared to $30 \%$ of teachers who gave similar answers. This item once again points to the importance of external exam preparation within the LA's role in practice.

Over one third of both LAs and teachers gave examples of projects in which the LA was a key player. Examples included cultural projects, drama and theater projects, literacy and reading projects, penpals, extracurricular activities, and school projects. General support, cited by almost one quarter of LAs and over $10 \%$ of teachers included materials creation, support of small groups of students, error correction in the classroom, and planning.

A few teachers wrote that LAs gave presentations cultural or content presentations, which was included in the teaching category. LAs did not mention presentations but did cite teaching the class, co-teaching, and substituting the teacher. Notably, this last item is strictly prohibited by all three programs and indicates a misuse of the LA.

Few LAs and teachers mentioned that LAs were involved in the classroom routines such as the assembly. Finally, one LA wrote that he or she did not consider themselves as important in the school, suggesting that he or she was not a key player in any activities.

\section{CONCLUSIONS}

At the beginning of the academic year, LAs and teachers have similar expectations regarding the LA's role. They generally coincide when describing language support as the main task for LAs, and in describing their role as an assisting one. However, their expectations do not always match their experiences later in the year. Many choose to employ collaboration or teaching verbs in their descriptions based on experience. They also describe more external exam preparation tasks and less cultural support or materials preparation. Therefo$\mathrm{re}$, whatever planning and preparation is done among the two groups early on may not be effective in preparing for LA participation throughout the year. A closer look is needed to match needs and reality to preparation and training in order to ensure that LAs are ready for the classroom situation that awaits them.
It is likewise important to underline the differences noted in teachers' and LAs' reported experiences. For example, there is a substantial variation in the percentages of teachers and LAs who report LAs teaching part of a group or the entire class group. This discrepancy is clearly seen when over $82 \%$ of LAs report teaching the entire group while less than $38 \%$ of teachers report the same. While the teachers and LAs who responded to the questionnaire do not necessarily work together, this disparity begs to be addressed. Similarly, teachers and LAs often place different relative importance on certain aspects. As an example, we see that many more LAs than teachers expected and reported the LA acting as a role model to students.

These discrepancies may be the result of a simple difference in perspective, suggesting that the two groups do not understand the same thing when faced with a certain term or description. In the first example, perhaps teachers are fearful to admit that they have asked LAs to teach the group, as if this is an admission of failure or a breach of their agreement with program administration. Or it may be a question of cultural perspective, in that the words «teach» or «role model» may be surrounded by a more formal connotation in the Spanish context. Whatever the case, it is clear that teachers and LAs sometimes describe the same situation using different words and placing varying emphasis on certain aspects of the role. This ought to remind us that the two collectives are of distinct perspectives which may need to be reconciled through common meetings or training sessions. Training on cultural differences might even be required for both groups in order to avoid potentially awkward situations as well as benefit from more harmonious efforts toward teaching and learning goals.

When considering the program documentation, cultural support and materials creation are cited as an important part of the LA role, but teachers and LAs seem to place little importance on these aspects. Indeed, when asked for their own descriptions, a small percentage of teachers and LAs expect significant cultural or material contributions, and even fewer report such support during the academic year. When presented with these two considerations as options in a list, many tick the box initially but less often once faced with the reality of the classroom. If these are key goals for bilingual programs, 
as it seems to be from the program documentation, the inclusion of culture in the classroom may need a boost through specific training or indications. Concerning the provision of teaching/learning materials, LAs might receive more specific indications regarding authentic materials that they might bring from their home countries, a measure that may also contribute to cultural lessons.

In the same way, program documentation does not contemplate the LA as having a role in preparation for external examinations. However, roughly three out of every four teachers and LAs report that LAs contribute to students' exam preparation. In fact, several in each group even consider it to be the LA's most effective contribution to the classroom. If LAs are to take part in this process in the classroom, it is logical that bilingual program administrations should acknowledge this contribution and help prepare LAs and teachers for the eventuality. On the contrary, they should prohibit or discourage the practice in order to employ LAs in other classroom ventures.

In summary, teachers and LAs expect much of the same from the role of the LA, though these expectations do not always coincide with the role as described in official documentation. Differences in perspective between the groups mainly arise when describing classroom experiences and when placing relative importance on particular aspects of the LA's role. When comparing classroom practices with program documentation, it is clear that cultural aspects and the provision of teaching/learning materials are not carried out as fully as intended by program administrations. On the other hand, LAs are often dedicated to preparing

\section{BIBLIOGRAPHY}

CM [2009]: Guía del auxiliar de conversación: Comunidad de Madrid (curso 2009-2010). Retrieved from: http://redined.mecd.gob.es/xmlui/handle/11162/43104 [Search: February 25, 2015].

[2014]: Guía del auxiliar de conversación: curso 20142015. Retrieved from: http://www.educa2.madrid.org/ web/educamadrid/principal/files/b205a2ee-682c41da-b886-376593c987b9/GUIA\%2014-15_espanol.pdf?t=1410179451311/GUIA\%2014-15.espanol. pdf?t=1405944676582 [Search: November 28, 2014].

FERE-CECA [2014]: Guidelines of best practices for conversation assistants (internal document).

\section{[...] teachers and LAs expect much of the same from the role of the LA, though these expectations do not always coincide with the role as described in official documentation}

students for external exams despite the lack of inclusion of this aspect in official role descriptions.

In order to conciliate program administrations', teachers' and LAs' expectations, it is recommended that those responsible for bilingual programs first reflect on the role that LAs should play in bilingual classrooms. As part of this reflection, it would be interesting to hold focus groups with experienced teachers and LAs in order to collect best practices and extend them throughout the program. Once the ideal LA role is clear, improved training and communication is needed to detail their responsibilities to teachers and LAs as well as demonstrate how to make the most of this resource. It is advisable that training and communication be promoted through digital platforms in order to reduce costs and make them more time efficient for everyone involved. These will be the first steps in applying the ideal LA role to classroom practices. Further research will then be required in order to ensure that the organizational changes have the desired effect in the classroom.

Fernández, R. and Halbach, A. [2010]: «Analysing the situation of teachers in the Madrid bilingual project after four years of implementation», in Y. Ruiz de Zarobe, J. M. Sierra and F. Gallardo del Puerto (eds.), Content and foreign language integrated learning: contributions to multilingualism in european contexts, Bern (Switzerland): Peter Lang, pp. 241-264.

FETE-UGT [2014]: Resultados de la encuesta al profesorado sobre el programa bilingüe de la Comunidad de Madrid (press release). Retrieved from: www.fetemadrid.es/informes/2014-09-30_encuestaBiliguismo. pdf [Search: January 24, 2015]. 
Gerena, L. and Ramírez-Verdugo, M. ${ }^{a}$ D. [2014]: «Analyzing bilingual teaching and learning in Madrid, Spain: a fulbright scholar collaborative research project», GIST: Education and Learning Research Journal, 8, pp. 118-136.

Hibler, A. [2010]: Effective collaboration between native and nonnative speakers in the Spanish CLIL context: the case of language assistants in primary education, Madrid: Universidad Complutense de Madrid. Retrieved from: http://eprints.ucm.es/12796/1/Hibler_Abbie. pdf [Search: July 16, 2013].

Ministerio de Educación, Cultura y Deporte [2014]: Guía: auxiliares de conversación extranjeros en España 2014/2015. Retrieved from: https://sede.educacion. gob.es/catalogotramites/profesores/convocatorias/extranjeros/auxiliares-conversacion-extranjerosespana. html [Search: January 30, 2015].

Nunan, D. [1992]: Research methods in language learning, Cambridge: Cambridge University Press.
Ortega Cebreros, A. M. ${ }^{a}$ [2003]: La experiencia pedagógica del auxiliar de conversación de lengua extranjera, Andalucía: Grupo Editorial Universitario.

Scobling, C. [2011]: El auxiliar de conversación como herramienta de motivación en la enseñanza y aprendizaje de lenguas extranjeras en la educación secundaria y bachillerato en España, Universidad Internacional de La Rioja. Retrieved from: http://www.mecd. gob.es/dctm/sede/catalogo-tramites/profesores/ extranjeros/auxilares-conversacionespana/2011proyec-investiga-candy-scobling-sobre-auxiliaresconversacion. pdf?documentld $=0901$ e $72 b 810 b 75 \mathrm{ce}$ [Search: November 3, 2015].

Tobin, N. and Abello-Contesse, C. [2012]: The use of native assistants as language and cultural resources in Andalusia's bilingual schools. Retrieved from: http:/l bolderenglish.com/graphics/N.Tobin_LAS.pdf [Search: July 17, 2013].

UCETAM [2012]: Bilingual cooperative schools: schools handbook 2012-2013 (internal document).

Este máster oficial [60 créditos ECTS] se inicia en febrero y octubre de cada año y su duración normal es de 12 meses.

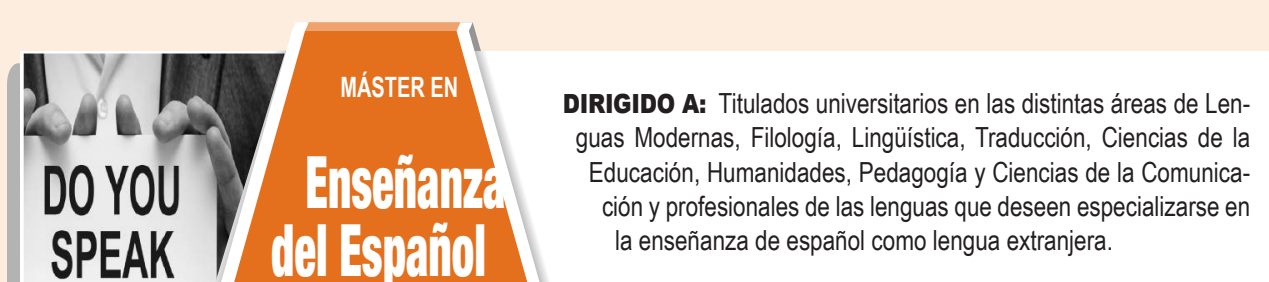

OBJETIVOS: Formar profesionales cualificados en el ámbito SPANISH? Gomo Lengyta de la enseñanza del español como lengua extranjera, dotándolos de un perfil práctico y competitivo que los capacite para realizar adecuadamente y con garantía de éxito su labor profesional, facilitándoles su integración en un mercado laboral de enorme proyección internacional. 


\section{Magisterio de Educación Infantil}

Hoy en día los centros educativos tienen una imperiosa necesidad de disponer de personal especializado, capaz de hacer frente a las necesidades educativas de la etapa infantil, de acuerdo con los conocimientos ya logrados por las diversas ciencias que hoy se ocupan de los niños en los primeros años de su vida, así como de los logros relativos al desarrollo de la inteligencia, la emocionalidad y la formación de la personalidad temprana, resultantes de estudios recientes sobre el desenvolvimiento de la mente infantil.

PLAN DE ESTUDIOS (la obtención del grado conlleva la realización de 240 créditos)

\begin{tabular}{|c|c|c|c|}
\hline CURSO & ASIGNATURAS & TIPO & CRÉD. \\
\hline 1 & Didáctica e Innovación Curricular en Educación Infantil ..... & $\mathrm{T}$ & 6 \\
\hline 1 & 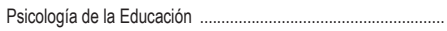 & $\mathrm{T}$ & 6 \\
\hline 1 & Historia y Teoria de la Educación ................................................. & $\mathrm{T}$ & 6 \\
\hline 1 & Tecnologias de la Información y Gestión del Conocimiento ......... & $\mathrm{T}$ & 6 \\
\hline 1 & 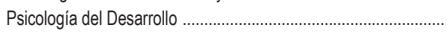 & $\mathrm{T}$ & 6 \\
\hline 1 & Desarrollo de Habilidades Lingüisticas y Lectoescritoras ............ & B & 6 \\
\hline 1 & 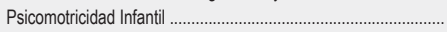 & $B$ & 6 \\
\hline 1 & 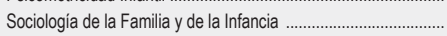 & $\mathrm{T}$ & 6 \\
\hline 1 & Organización y Gestión del Aula & $\mathrm{T}$ & 6 \\
\hline 1 & Métodos, Recursos y Nuevas Tecnologías para el Aprendizaje .. & $\mathrm{T}$ & 6 \\
\hline 2 & Conocimiento del Medio Social y Cultural y su Didáctica ............. & $B$ & 6 \\
\hline 2 & 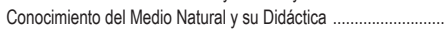 & B & 6 \\
\hline 2 & Lengua Extranjera para Maestros: Inglés ......................................... & B & 6 \\
\hline 2 & 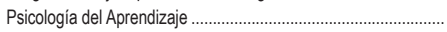 & $\mathrm{T}$ & 6 \\
\hline 2 & 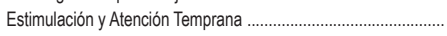 & $\mathrm{T}$ & 6 \\
\hline 2 & Sociología de la Educación. & $\mathrm{T}$ & 6 \\
\hline 2 & Expresión Musical y su Didáctica ......... & B & 6 \\
\hline 2 & Desarrollo del Pensamiento Lógico Matemático y su Didáctica .. & B & 6 \\
\hline 2 & PRÁCTICAS EXTERNAS I & B & 12 \\
\hline 3 & Lengua y Literatura y su Didáctica .................... & $\mathrm{B}$ & 6 \\
\hline 3 & Atención a la Diversidad en Educación Infantil ... & $\mathrm{T}$ & 6 \\
\hline 3 & Didáctica de la Lengua Inglesa en Educación Infantil . & $B$ & 6 \\
\hline 3 & Metodología de la Investigación en Educación ............... & $\mathrm{T}$ & 6 \\
\hline 3 & 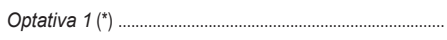 & 0 & 6 \\
\hline 3 & Organización y Liderazgo de Centros Escolares ......... & $\mathrm{T}$ & 6 \\
\hline 3 & Orientación e Intervención Tutorial ....................... & $\mathrm{T}$ & 6 \\
\hline 3 & 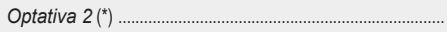 & 0 & 6 \\
\hline 3 & PRÁCTICAS EXTERNAS ॥ .... & $B$ & 12 \\
\hline 4 & El Juego en Educación Infantil ........... & $\mathrm{T}$ & 6 \\
\hline 4 & Expresión Plástica y Visual y su Didáctica ....... & $B$ & 6 \\
\hline 4 & Optativa $3\left({ }^{*}\right)$ & 0 & 6 \\
\hline 4 & Optativa $4\left(^{*}\right)$ & 0 & 6 \\
\hline 4 & 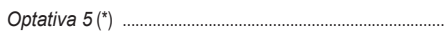 & 0 & 6 \\
\hline 4 & Salud, Infancia y Alimentación . & $\mathrm{T}$ & 4 \\
\hline 4 & PRÁCTICAS EXTERNAS III & B & 12 \\
\hline 4 & TRABAJO FIN DE GRADO & B & 14 \\
\hline
\end{tabular}

\section{Magisterio de Educación Primaria}

Son objetivos de la Educación Primaria, entre otros: conocer y apreciar los valores y las normas de convivencia, aprender a obrar de acuerdo con ellas, prepararse para el ejercicio activo de la ciudadanía y respetar los derechos humanos, así como el pluralismo propio de una sociedad democrática. También, desarrollar hábitos de trabajo individual y de equipo, de esfuerzo y responsabilidad en el estudio, así como actividades de confianza en uno mismo, sentido crítico, iniciativa personal, curiosidad, interés y creatividad en el aprendizaje.

PLAN DE ESTUDIOS (la obtención del grado conlleva la realización de 240 créditos)

\begin{tabular}{|c|c|c|c|}
\hline CURSO & ASIGNATURAS & TIPO & CRÉD. \\
\hline 1 & Didáctica e Innovación Curricular en Educación Primaria ............. & $\mathrm{T}$ & 6 \\
\hline 1 & Psicologia de la Educación ........ & $\mathrm{T}$ & 6 \\
\hline 1 & 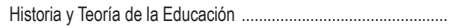 & $\mathrm{T}$ & 6 \\
\hline 1 & Tecnologias de la Información y de Gestión del Conocimiento ... & $\mathrm{B}$ & 6 \\
\hline 1 & 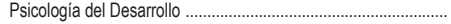 & $\mathrm{T}$ & 6 \\
\hline 1 & 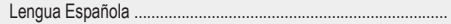 & B & 6 \\
\hline 1 & 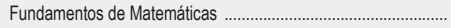 & B & 6 \\
\hline 1 & Conocimiento del Medio Natural & B & 6 \\
\hline 1 & Sociologia de la Educación & $\mathrm{T}$ & 6 \\
\hline 1 & Métodos, Recursos y Nuevas Tecnologias para el Aprendizaje .. & B & 6 \\
\hline 2 & Atención a la Diversidad en Educación Primaria .............................. & $\mathrm{T}$ & 6 \\
\hline 2 & 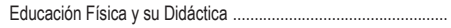 & B & 6 \\
\hline 2 & Lengua Extranjera para Maestros: Inglés .......................... & B & 6 \\
\hline 2 & 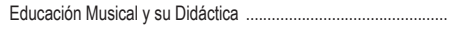 & B & 6 \\
\hline 2 & 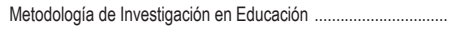 & $\mathrm{T}$ & 6 \\
\hline 2 & Organización y Liderazgo de Centros Escolares .............................. & $\mathrm{T}$ & 6 \\
\hline 2 & 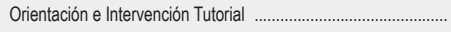 & $\mathrm{T}$ & 6 \\
\hline 2 & 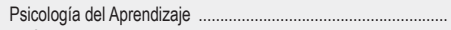 & $\mathrm{T}$ & 6 \\
\hline 2 & PRÁCTICAS EXTERNAS I & B & 12 \\
\hline 3 & 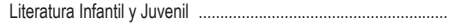 & B & 6 \\
\hline 3 & Didáctica de las Matemáticas & B & 6 \\
\hline 3 & Didáctica de la Lengua Inglesa en Educación Primaria ................ & B & 6 \\
\hline 3 & 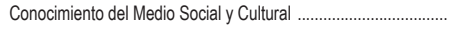 & B & 6 \\
\hline 3 & 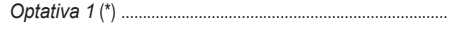 & 0 & 6 \\
\hline 3 & Didáctica de las Ciencias Sociales ........................ & B & 6 \\
\hline 3 & 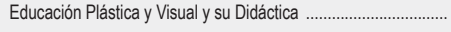 & B & 6 \\
\hline 3 & Optativa $2\left({ }^{*}\right)$ & 0 & 6 \\
\hline 3 & PRÁCTICAS EXTERNAS $\|$ & B & 12 \\
\hline 4 & Didáctica de las Ciencias Experimentales ........... & $\mathrm{B}$ & 6 \\
\hline 4 & 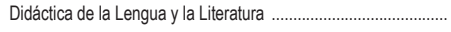 & B & 6 \\
\hline 4 & Optativa $3(*)$ & 0 & 6 \\
\hline 4 & Optativa $4\left({ }^{*}\right)$ & 0 & 6 \\
\hline 4 & Optativa $5\left({ }^{*}\right)$ & 0 & 6 \\
\hline 4 & Educación en Valores ............ & B & 4 \\
\hline 4 & 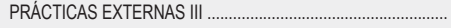 & B & 12 \\
\hline 4 & TRABAJO FIN DE GRADO & B & 14 \\
\hline
\end{tabular}

$\left(^{*}\right)$ La lista de asignaturas optativas se puede consultar en www.udima.es. $\quad \mathrm{T}=$ Formación básica; $\mathrm{B}=$ Formación obligatoria; $\mathrm{O}=$ Asignatura optativa 


\section{Menciones en los grados de Magisterio}

\section{Menciones en los grados de Magisterio de Educación Infantil y Primaria}

Los grados en Magisterio de Educación Infantil y Primaria tienen cinco menciones. Cada una de ellas se compone de 30 créditos ECTS, pudiendo los estudiantes optar por una de las menciones para poder finalizar el grado o bien obtener el título sin mención cursando 30 créditos optativos a su libre elección de los ofertados. También podrían cursar más de una mención. Si el alumno deseara obtener varias menciones, deberá cursar los créditos asociados a cada una de ellas.

\begin{tabular}{|c|c|}
\hline \multicolumn{2}{|l|}{ Mención en Lengua inglesa } \\
\hline Asignatura & ETCS \\
\hline Lengua inglesa $\mathrm{I}$................. & 6 \\
\hline 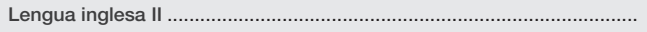 & 6 \\
\hline 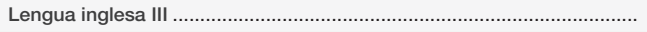 & 6 \\
\hline Educación para el bilingüismo: CLIL & 6 \\
\hline Didáctica avanzada de la lengua inglesa. & 6 \\
\hline
\end{tabular}

\begin{tabular}{|c|c|}
\hline \multicolumn{2}{|l|}{ Mención en Pedagogía terapéutica } \\
\hline Asignatura & ETCS \\
\hline 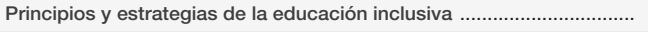 & 6 \\
\hline Evaluación y orientación psicopedagógica . & 6 \\
\hline Necesidades específicas de apoyo educativo y orientación familiar & 6 \\
\hline Intervención psicopedagógica en dificultades de aprendizaje . & 6 \\
\hline $\begin{array}{l}\text { Programas de intervención para alumnos con necesidades específicas } \\
\text { de apoyo educativo }\end{array}$ & 6 \\
\hline
\end{tabular}

\begin{tabular}{|l|l|}
\hline \multicolumn{3}{|c|}{ Mención en Audición y lenguaje } \\
\hline Asignatura & ETCS \\
\hline
\end{tabular}

Principios y estrategias de la educación inclusiva................................... 6

Trastornos del habla y del lenguaje ..................................................... 6

Sistemas alternativos y aumentativos de comunicación ........................ 6

Evaluación e intervención en lenguaje oral............................................. 6

Evaluación e intervención en lenguaje escrito ....................................... 6

\begin{tabular}{|c|c|}
\hline \multicolumn{2}{|l|}{ Mención en Tecnología educativa } \\
\hline Asignatura & ETCS \\
\hline Recursos tecnológicos e innovación docente....... & 6 \\
\hline Desarrollo tecnológico y educación intercultural .. & 6 \\
\hline 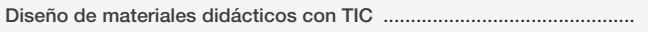 & 6 \\
\hline Integración de las TIC en la enseñanza de las artes y las humanidades & 6 \\
\hline Integración de las TIC en la enseñanza de las ciencias y las matemáticas & 6 \\
\hline
\end{tabular}

\begin{tabular}{|l|l|}
\hline \multicolumn{3}{|c|}{ Mención en Enseñanza de la religión católica* } \\
\hline Asignatura & ETCS \\
\hline
\end{tabular}

Historia de la Iglesia ...................................................................... 6

Religión, cultura y valores ............................................................... 6

El mensaje cristiano ...................................................................... 6

La Iglesia, los sacramentos y la moral ............................................. 6

Pedagogía y didáctica de la religión católica ......................................... 6

* Cubre los requisitos de formación universitaria para poder solicitar la DECA a la Conferencia Episcopal (ver plan de estudios).

\section{Curso de adaptación al grado}

Este curso de adaptación al grado ofrece a los maestros diplomados en la Especialidad de Educación Infantil o Primaria la posibilidad de obtener formación en campos determinados dentro del ejercicio profesional docente en estas etapas, a través de las menciones cualificadoras mencionadas anteriormente.

El objetivo principal del plan de estudios de este curso de adaptación al grado es contribuir a la actualización de la formación de los maestros diplomados. La aplicación de las TIC a la educación y de líneas pedagógicas innovadoras fruto de la investigación en educación hacen necesaria la actualización de los conocimientos didácticos de los diplomados y la formación de los maestros en investigación e innovación.

Al finalizar el curso de adaptación se obtiene el título de grado en Magisterio de Educación Infantil o de Educación Primaria.

La docencia en la etapa de educación infantil o primaria es una profesión regulada. Los graduados en Magisterio de Educación Infantil o Primaria tienen como principal salida profesional el trabajo como profesores en estas etapas, tanto en centros públicos como concertados y privados.

Si bien otras salidas profesionales para estos títulos pueden ser:

- Participación en proyectos educativos de organismos e instituciones (centros culturales, museos, asociaciones, ONG, etc.).

- Centros de educación para adultos.

- Centros de ocio y tiempo libre.

- Participación en programas de extensión educativa (actividades extraescolares, actividades de apoyo, etc.).

- Diseño y elaboración de materiales didácticos.

- Participación en proyectos de atención a la infancia y familiar. 


\section{/ Objetivo cumplido:}

G6 Aprobar la oposición

Rubén Álvarez

I Técnico de Auditoría y Contabilidad
OPOSICIONES A TÉCNICOS

DE AUDITORIA Y CONTABILIDAD

CONVOCATORIA 2016 - Online

\section{Formando profesionales desde 1977}

\section{OPOSICIONES • MÁSTERES - CURSOS • SEMINARIOS}

Prepara una oposición en el centro líder en resultados, formándote de manera presencial u online.
(4) Inspectores de Entidades de Crédito (Banco de España)
(A) Técnicos Superiores de la Administración General (Madrid, Cataluña y Comunidad Valenciana)
(4) Inspectores de Seguros del Estado
(4) Administradores Civiles del Estado
(A) Superior de Sistemas y Tecnologías de la Administración del Estado
(A) Inspectores de Hacienda del Estado
(A) Interventores y Auditores del Estado
(4) Secretarios de la Administración Local
(Ai) Inspectores de Trabajo y Seguridad Social
(4) Interventores-Tesoreros de la Administración Local
(A) Secretarios-Interventores de la Administración Local
(A) Interventores de la Seguridad Social
(A) Técnicos de la Seguridad Social
(A1) Jueces y Fiscales y Letrados de la Administración de Justicia

(22) Técnicos de Hacienda
(2) Gestión de Sistemas e Informática del Estado

(12) Gestión de la Seguridad Social

(A2) Subinspectores Laborales

(A2) Gestión Procesal y Administrativa

(A2) Técnicos de Auditoría y Contabilidad

(ㄱ) Tramitación Procesal y Administrativa

(ㄷ) Agentes de la Hacienda Pública

Y muchas más... Consulta en www.cef.es

¡Busca la tuya! 